\title{
PEMANFAATAN PASIR LAUT TERAKTIVASI ASAM SEBAGAI AGEN ADSORBSI LOGAM Cr (IV) Pada Limbah Pengolahan Kulit
}

\author{
Shinta Aprilawati, Eko malis, Dewi sartika \\ Fakultas Matematika dan Ilmu Pengetahuan AlamUniversitas PGRI Banyuwangi \\ email korespondensi : shinta@gmail.com
}

\begin{abstract}
ABSTRAK
Kromium (Cr) merupakan salah satu logam berat yang dapat menyebabkan pencemaran lingkungan. Salah satu metode pemisahan yang dapat dilakukan untuk mengurangi pencemaran lingkungan adalah metode adsorpsi. Tujuan penelitian ini adalah untuk mengetahui apakah pasir laut yang teraktivasi asam sulfat dapat digunakan sebagai adsorben anion logam $\mathrm{Cr}$ (total) yang terdapat dalam limbah pabrik kulit. Variasi penelitian ini meliputi penentuan $\mathrm{pH}$ optimum, konsentrasi optimum, penentuan waktu optimum, serta penentuan persen adsorpsi pasir laut teraktivasi $\mathrm{H} 2 \mathrm{SO} 4$ untuk menurunkan kadar ion logam $\mathrm{Cr}$ (total) pada limbah pabrik kulit dengan menggunakan spektrofotometer serapan atom (SSA). Variasi pH dilakukan pada pH 3, 5, 7, dan 9. Variasi konsentrasi dilakukan pada 100, 150, 200, 250 ppm. Variasi waktu dilakukan pada 30, 60, 90, dan 120 menit. Kapasitas adsorpsi semakin meningkat seiring peningkatan $\mathrm{pH}$ akan menyebabkan terlepasnya ion-ion (karbonat) ke dalam larutan. Semakin lama waktu kontak memungkinkan terjadinya peningkatan penyerapan ion logam. Interaksi yang terlalu lama dapat menurunkan tingkat penyerapan. Hal ini disebabkan semakin lama waktu kontak dapat mengakibatkan desorpsi, yaitu lepasnya ion logam $\mathrm{Cr}$ (total) yang sudah terikat pada gugus aktif adsorben. Adsorben paling optimum adalah pasir hitam teraktivasi H2SO4 2M. Sebanyak 6,5 gram pasir hitam teraktivasi $\mathrm{H} 2 \mathrm{SO} 4$ 2M digunakan untuk menyerap limbah dengan konsentrasi $1,86 \mathrm{mg} / \mathrm{L}$. Kapasitas adsorpsi yang diperoleh $0,33 \mathrm{mg} / \mathrm{L}$ dengan presentase dalam menyerap ion $\begin{array}{llllll}\text { logam } & \mathrm{Cr} & \text { (total) } & \text { sebesar } & 82,2 & \% \text {. }\end{array}$
\end{abstract} Kata Kunci : Adsorpsi, Pasir Laut, $\operatorname{Cr}($ total $)$ 


\begin{abstract}
Chromium $(\mathrm{Cr})$ is one of the heavy metals that can cause environmental pollution. One method of separation that can be done to reduce environmental pollution is the adsorption method. The purpose of this study was to determine whether sea sand activated by sulfuric acid could be used as an adsorbent for $\mathrm{Cr}$ (total) metal anions contained in leather factory waste. Variations in this study include the determination of optimum $\mathrm{pH}$, optimum concentration, optimum timing, and determination of percent adsorption of sea sand activated by $\mathrm{H} 2 \mathrm{SO} 4$ to reduce the level of $\mathrm{Cr}$ (total) metal ions in skin factory waste using atomic absorption spectrophotometer (AAS).

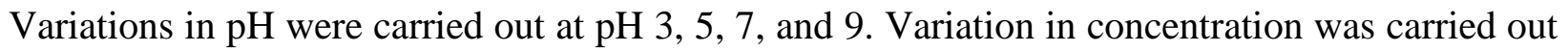
at 100, 150, 200, $250 \mathrm{ppm}$. Variations in time are carried out at 30, 60, 90, and 120 minutes. Adsorption capacity increases as $\mathrm{pH}$ increases, causing the release of ions (carbonate) into solution. The longer contact time allows for increased absorption of metal ions. Interactions that take too long can reduce absorption rates. This is due to the longer contact time can lead to desorption, namely the release of metal ions $\mathrm{Cr}$ (total) that has been bound to the adsorbent active group. The most optimum adsorbent is $\mathrm{H} 2 \mathrm{SO} 42 \mathrm{M}$ activated black sand. A total of 6.5 grams of activated black sand $\mathrm{H} 2 \mathrm{SO} 42 \mathrm{M}$ is used to absorb waste with a concentration of 1.86 mg. Adsorption capacity obtained was $0.33 \mathrm{mg} / \mathrm{L}$ with a percentage of absorbing $\mathrm{Cr}$ (total) ionicionby $82.2 \%$.
\end{abstract} Key words: Adsorption, sea sand, Cr (total) 


\section{PENDAHULUAN}

Kondisi air yang bersih saat ini sudah semakin sedikit, masalah pada air saat ini perlu mendapat perhatian serius . Kondisi air saat ini sudah banyak yang tercemar oleh limbah dan berbagai macam hasil kegiatan manusia, Menjadi barang mahal saat ini untuk mendapatkan air yang sesuai standart. Sumber daya air secara kualitas telah mengalami Penurunan. Demikian pula secara kuantitas, ketersediaan air sudah tidak mampu memenuhi kebutuihan manusia yang terus meningkat.Penyebab adanya pencemaran pada air antara lain jika air terkontminasi oleh bahan pencemar seperti limbah rumah tangga, limbah industri, dan sisa-sisa pupuk dan pestisida dari daerah pertanian dan sebagainya.

Pencemaran air oleh logam berat yang bersifat toksik saat ini sering terjadi, jenis polutan logam berat antara lain kobalt (Co), tembaga $(\mathrm{Cu})$, kromium $(\mathrm{Cr})$, timbal $(\mathrm{Pb})$, kadmium $(\mathrm{Cd})$, perak $(\mathrm{Ag})$, nikel $(\mathrm{Ni})$, merkuri $(\mathrm{Hg})$, arsen (As), seng ( $\mathrm{Zn})$, besi $(\mathrm{Fe})$, dan mangan (Mn). Jika air yang mengandung logam-logam tersebut dikonsumsi oleh manusia maupun makhluk hidup lainya dan terakumulasi dalam waktu yang lama dapat bersifat toksik dan tidak dapat diurai oleh organ tubuh.
Logam kromium (Cr) salah satu logam berat yang merupakan sumber polusi dan perlu dihilangkan dalam perairan. Logam tersebut digunakan dalam industri tekstil, industri cat, industri pelapisan logam, dan penyamakan kulit. Air limbah yang mengandung logam kromium dan terkonsumsi oleh manusia dapat menimbulkan keracunan dan gangguan pada organ vital seperti syaraf pusat dan kanker. Berdasarkan keputusan menteri Negara Lingkungan Hidup Nomor : (menteri negara lingkungan hidup, 2010) menyatakan bahwa baku mutu air limbah bagi kawasan industri untuk parameter kromium total maksimal adalah $1 \mathrm{mg} / \mathrm{L}$. Oleh karena itu perlu adanya upaya untuk mengurangi kadar limbah yang mengandung kromium sebelum dibuang ke lingkungan.

Banyak metode pemisahan yang telah dikembangakan untuk menangani masalah limbah di perairan, antara lain presipitasi, pertukaran ion, dan adsorpsi. Metode presipitasi adalah proses pembentukan endapan dalam larutan, metode ini paling ekonomis tetapi menimbulkan masalah baru pada endapan yang di hasilkan. metode pertukaran ion atau osmosis adalah sebuah proses kromatografi untuk memisahkan molekul ion suatu senyawa berdasarkan perbedaan nilai 
muatan permukaan antar senyawa, metode tersebut baik pada umumnya efektif, tetapi memrlukan biaya yang relatis cukup tinggi. Sedangkan metode adsorpsi adalah suatu proses yang terjadi ketika suatu fluida, cairan, maupun gas, terikat pada suatu padatan atau cairan (adsorben) dan akhirnya membentuk suatu lapisan tipis pada permukaanya, metode adsorpsi telah terbukti efektif untuk mengurangi konsentrasi logam di perairan seperti yang dilaporkan oleh berbagai penelitian, diantaranya melalui penggunaan berbagai adsorben seperti zeolit (Muhammad Said, 2008). Berdasarkan penelitian (DS Pambudi, 2014), pasir dapat digunakan sebagai penjerap (adsorben) logam berat yang terdapat pada limbah industri sebelum dibuang ke lingkungan perairan. Karena di wilayah Kabupaten Banyuwangi sebagian besar adalah wilayah pesisir laut untuk itu dalam penelitian ini menggunakan pasir laut sebagai adsorben. Dimana pasir laut yang digunakan ada dua variasi, yaitu pasir laut berwana hitam dan pasir laut berwarna putih.

Pasir laut berwarna hitam dan pasir laut berwarna putih kemungkinan mempunyai kemampuan mengadsorpsi logam berat yang berbeda-beda Agar hasil adsorpsi lebih maksimal kedua pasir tersebut perlu di modifikasi lebih dahulu. Untuk meningkatkan kemampuan adsopsi pasir laut terhadap logam toksik maka perlu diaktivasi secara kimia menggunakan larutan asam ataupun basa. Asam sulfat (H2SO4) adalah asam mineral (anorganik) yang kuat dan zat ini larut dalam air dalam semua perbandingan. Hal ini telah didukung oleh beberapa hasil penelitian, yakni (dwimas, 2013). Penggunaan pasir laut warna hitam dan warna putih yang diaktivasi dengan $\mathrm{H} 2 \mathrm{SO} 4$ dan disalut $\mathrm{Fe} 2 \mathrm{O} 3$ dapat meningkatkan luas permukaan pasir sehingga dapat menjadi adsorben yang baik dalam mengadsorpsi logam $\mathrm{Cu}$ (II) dalam suatu larutan.Telah melakukan. Hasilnya, dapat meningkatkan beberapa sifat fisik dan kimianya seperti keasaman permukaan dan porositasnya sehingga lebih efektif sebagai adsorben.

Oleh karena itu, penulis akan melakukan modifikasi terkombinasi terhadap pasir tersebut yaitu diaktivasi dengan asam sulfat. Dengan modifikasi terkombinasi tersebut diharapkan kapasitas adsorpsinya terhadap ion logam $\mathrm{Cr}$ (total) dalam air limbah pabrik kulit lebih optimum dibandingankan dengan pasir biasa. Maka, sesuai dengan uraian diatas perlu adanya penelitian lebih lanjut tentang

\section{METODE PENELITIAN}




\section{Bahan}

Pasir laut hitam dari pantai Gumuk Kantong di Banyuwangi, Pasir laut putih dari pantai Bama di Banyuwangi, Airl imbah pabrik kulit, K2Cr2O7, $\mathrm{H} 2 \mathrm{SO} 4$, HNO3 1\%, NaOH, HCl.

\section{Alat}

Oven listrik, ayakan 100 Mesh, magnetic stirrer, indikator universal, Neraca Analitik, Kertas saring whatman No 42, Pencatat waktu (stop watch), Spektrofotometer Serapan Atom, Beaker glass $100 \mathrm{~mL}$, Labu ukur $500 \mathrm{~mL}$, Labu ukur $100 \mathrm{~mL}$, Pipet tetes, Pipet volume, Gelas arloji, Batang pengaduk, Spatula, Desikator.

\section{PROSEDUR KERJA}

\section{1) Preparasi pasir laut}

Bersihkan pasir laut hitam dan pasir laut putih dengan aquades dan dikeringkan, kemudian diayak dengan ayakan 100 mesh, sehingga diperoleh pasir laut dengan luas permukaan yang hampir sama. Pasir tersebut direndam menggunakan asam nitrat $1 \%$ selama 24 jam, selanjutnya disaring dan dibilas menggunkan aquades sampai $\mathrm{pH}$ larutan netral. Pasir tersebut kemudian dikeringkan dalam oven dalam suhu $105 \mathrm{C}$ selama 12 jam . Menghasilkan sampel pasir laut hitam dan putih yang sudah dipreparasi.

\section{2) Aktivasi pasir laut dengan asam sulfat} (H2SO4)

Ke dalam 4 buah erlenmeyer dimasukkan masing-masing 50 gram pasir laut warna hitam. $100 \mathrm{~mL}$ lautan asam sulfat masing-masing $1 \mathrm{M}, 2 \mathrm{M}, 3 \mathrm{M}$, dan $4 \mathrm{M}$ di masukan kedalam pasir hitam sambil diaduk dengan pengaduk magnet. Masukan juga 50 gram pasir laut hitam kedalam erlenmeyer dengan di tambahkan $100 \mathrm{~mL}$ aquades. Aktivasi dilakukan selama 24 jam kemudian disaring dan residu yang didapat dicuci dengan air panas lalu dikeringkan dalam oven pada temperatur $110-120^{\circ} \mathrm{C}$. Setelah kering, pasir laut disimpan di dalam desikator. Perlakuan yang sama dilakukan terhadap pasir laut warna putih (Widihati, 2008)

\section{3) Penentuan pH Optimum Penentuan pH Optimum}

Larutan Cr 100 ppm Sebanyak 250 $\mathrm{mL}$ dimasukkan ke dalam 4 buah erlenmeyer $250 \mathrm{~mL}$. Setiap erlenmeyer diatur keasamannya pada $\mathrm{pH} 3,5,7$, dan 9 dengan menambahkan $\mathrm{HCl}$ atau $\mathrm{NaOH}$. Kemudian dimasukkan 2,5 g pasir laut terakaktivasi $\mathrm{H} 2 \mathrm{SO} 4$ optimum ke dalam 
masing-masing $\mathrm{pH}$. Tabung digojok selama 30 menit pada suhu kamar, disaring, diukur volume filtratnya dan filtrat tersebut dianalisis dengan alat SSA. Lakukan pula pada pasir laut putih (Ramadhan, 2005).

\section{4) Penentuan Konsentrasi Optimum}

Sebanyak $250 \mathrm{~mL}$ larutan $\mathrm{Cr} 100$ ppm, 150 ppm, 200 ppm, dan 250 ppm dengan $\mathrm{pH}$ optimum dimasukkan ke dalam 4 buah erlenmeyer $250 \mathrm{~mL}$. Kemudian dimasukkan 2,5 g pasir laut terakaktivasi H2SO4 optimum pada setiap konsentrasi. Masing-masing digojok selama 30 menit, disaring, dan diukur volume filtratnya. Filtrat tersebut dianalisis dengan alat SSA. Lakukan pula pada pasir laut putih (Ramadhan, 2005).

\section{5) Penentuan Waktu Optimum}

Sebanyak $250 \mathrm{~mL}$ larutan $\mathrm{Cr}$ dengan $\mathrm{pH}$ dan konsentrasi optimum dimasukkan ke dalam 4 buah erlenmeyer $250 \mathrm{~mL}$. Kemudian dimasukkan 2,5 g pasir laut terakaktivasi $\mathrm{H} 2 \mathrm{SO} 4$ optimum pada masingmasing erlenmeyer. Campuran diaduk selama 5 menit. Penentuan waktu seimbang dilakukan dengan cara membuat waktu kontak selama 30, 60, 90, dan 120 menit untuk masingmasing erlenmeyer setiap perlakuan. kemudian larutan dipisahkan dari campuran dengan cara penyaringan. Filtrat yang diperoleh diukur absorbansinya dengan SSA

(dwimas,

2013).

\section{6) Aplikasi pasir laut terhadap limbah} Pabrik Kulit

\section{a. Penentuan Konsentrasi Awal Limbah Pabrik Kulit}

Sampel air limbah disaring kemudian diawetkan dengan menambahkan HNO3 pekat sampai $\mathrm{pH}$ kurang dari 2. Memasukkan $100 \mathrm{~mL}$ sampel air limbah kedalam gelas piala yang sudah dikocok sampai homogen ditambah $5 \mathrm{~mL}$ asam nitrat dan dipanaskan di pemanas listrik sampai larutan hampir kering. Kemudian $50 \mathrm{~mL}$ aquades dimasukkan dalam labu ukur 100 $\mathrm{mL}$ melalui kertas saring ditepatkan $100 \mathrm{~mL}$ dengan aquades dan dianalisis dengan SSA (BSN, SNI 06- 6989 17-2004).

\section{b. Penentuan konsentrasi Cr Total dalam sampel setelah diadsorpsi}

Sebanyak 32,5 g Pasir laut terakaktivasi $\mathrm{H} 2 \mathrm{SO} 4$ optimum dimasukkan dalam $250 \mathrm{~mL}$ sampel yang telah diketahui kadarnya pada preparasi sampel air limbah elektroplating, di atur konsentrasi dan $\mathrm{pH}$ pada kondisi yang memberikan serapan 
optimum, kemudian diaduk sampai batas waktu optimum. Larutan disaring dan tepatkan dalam labu ukur $50 \mathrm{~mL}$, lalu dianalisis dengan SSA.

\section{HASIL DAN PEMBAHASAN}

\section{Pembuatan Adsorben Pasir Laut}

Pasir laut hitam dan putih diayak dengan ayakan 100 mesh. Masing-masing pasir laut sebanyak 50 gram terlebih dahulu dicuci menggunakan aquades dan dikeringkan. Pasir laut direndam dengan asam nitrat $1 \%$ selama 24 jam kemudian disaring dan dibilas dengan aquades sampai $\mathrm{pH}$ netral. Selanjutnya dikeringkan dalam oven pada temperatur $105^{\circ} \mathrm{C}$ selama 12 jam. Proses aktivasi menggunakan asam sulfat dapat membuat proses adsorpsi lebih optimal. Hal tersebut dikarenakan pada saat proses aktivasi dapat meningkatkan luas spesifik permukaan pori dan dengan asam sulfat dapat melarutkan pengotor dan mulut pori lebih terbuka.

Hal tersebut berpengaruh terhadap daya adsorpsi, semakin meningkat luas permukaan spesifik pori maka daya adsorpsi akan semakin meningkat. Masing-masing pasir laut dilakukan variasi aktivasi, yaitu
Aktivasi pasir laut hitam dengan asam sulfat $1 \mathrm{M}, 2 \mathrm{M}, 3 \mathrm{M}$, dan $4 \mathrm{M}$, dilakukan pula pada pasir laut berwarna putih yang diaktivasi dengan asam sulfat $1 \mathrm{M}, 2 \mathrm{M}, 3$ M, dan 4 M. Aktivasi dilakukan dengan cara memasukan masing-masing 50 gram pasir laut kedalam 4 buah erlenmeyer. Setiap erlenmeyer ditambahkan $100 \mathrm{~mL}$ Asam sulfat $1 \mathrm{M}, 2 \mathrm{M}, 3 \mathrm{M}$, dan $4 \mathrm{M}$. Masukan juga 50 gram pasir hitam dan 50 gram pasir putih kedalam 2 buah erlenmeyer dan ditambahkan dengan aquades sebanyak 100 $\mathrm{mL}$. kemudian diaduk dengan pengaduk magnet selama 5 menit dan di diamkan selama 24 jam, kemudian disaring dan residu yang di dapat di cuci dengan air panas agar terbebas dari ion sulfat. 


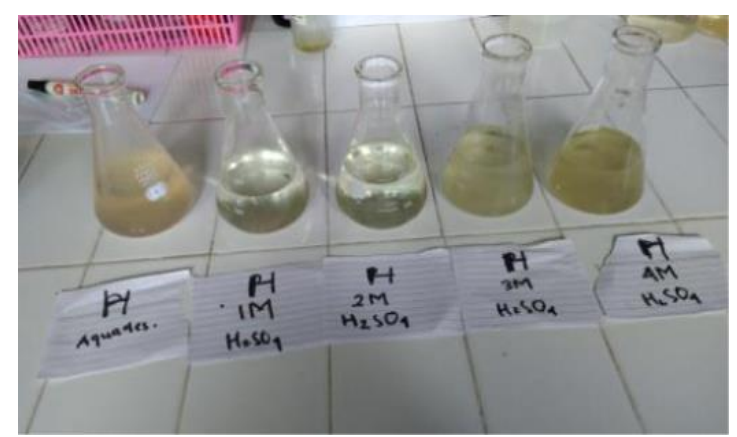

Gambar 1. Larutan hasil aktivasi pasir laut hitam dengan asam sulfat dan aquades

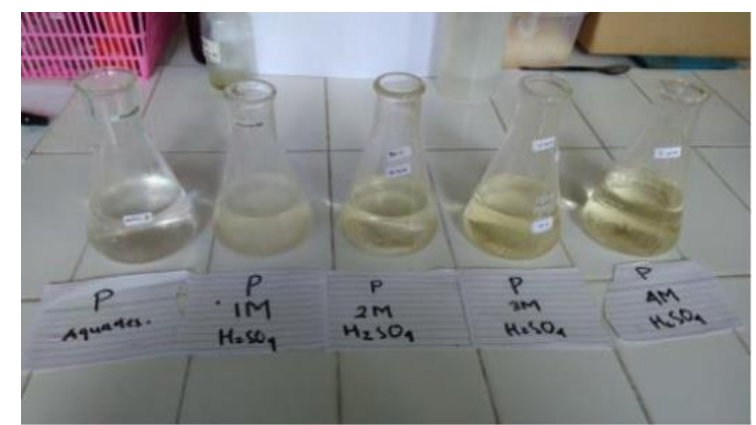

Gambar 2. Larutan hasil aktivasi pasir laut putih dengan asam sulfat dan aquades

Dari perlakuan tersebut di dapatkan filtrat dan residu. Dari proses penyaringan filtrat pasir yang diaktivasi dengan asam sulfat 2 $\mathrm{M}$ dan pasir laut putih dengan aquades atau tanpa perlakuan mendapatkan hasil filtrat yang paling bagus dan bening. Hal tersebut dikarenakan pada saat proses aktivasi pasir laut putih hancur dan terdapat bubuk berwarna putih. Oleh karena itu pada penelitian ini menggunakan pasir laut berwarna hitam yang sudah di aktivasi dengan asam sulfat $2 \mathrm{M}$.

2.Pengaruh pH terhadap Adsorpsi Ion Logam Cr (Total)
Proses adsorpsi Cr (Total) dengan menggunakan adsorben pasir laut dipengaruhi oleh $\mathrm{pH}$. Penentuan $\mathrm{pH}$ optimum dilakukan untuk mengetahui harga $\mathrm{pH}$ yang paling sesuai dimana penyerapan logam Cr (Total) oleh pasir laut mencapai kondisi optimal. Optimasi $\mathrm{pH}$ larutan tembaga terhadap penyerapan kromium oleh adsorben pasir laut dilakukan pada $\mathrm{pH} 3,5$, 7, dan 9. Pemilihan nilai $\mathrm{pH}$ ini didasarkan pada kemampuan pasir laut dalam mengadsorpsi ion logam kromium. Harga $\mathrm{pH}$ yang terlalu rendah dihindari untuk mencegah terjadinya persaingan proton 
dengan ion logam. Sedangkan $\mathrm{pH}$ terlalu tinggi dihindari untuk mencegah terjadinya hidroksida logam yang mungkin terjadi.
Data yang diperoleh setelah melakukan optimasi pH pada logam $\mathrm{Cr}$ (Total) dapat dilihat pada Gambar 3.

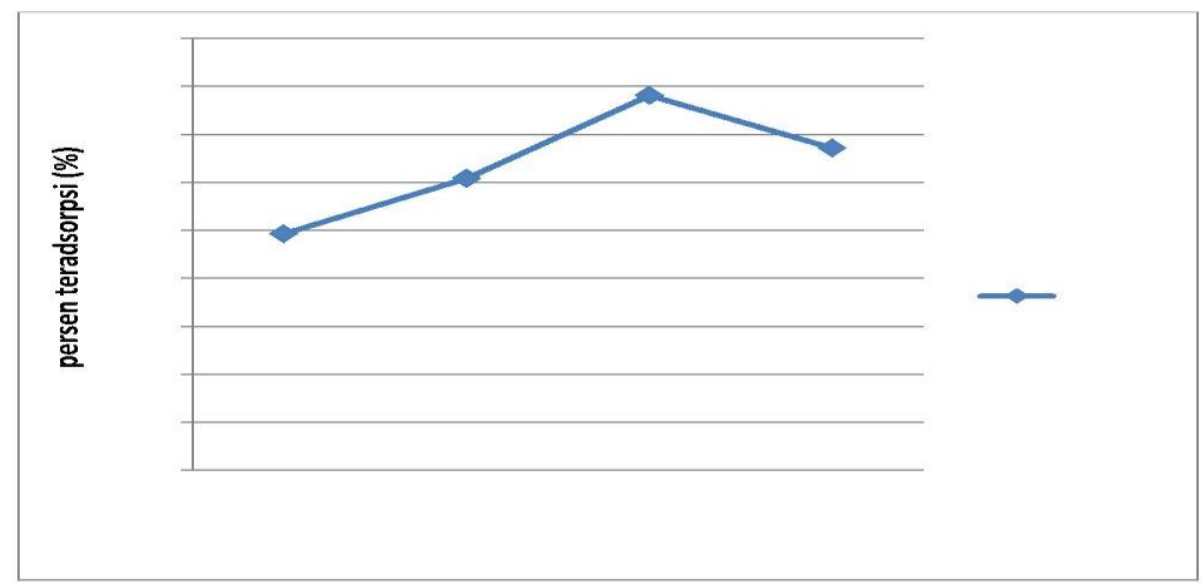

Gambar 3. Hubungan antara pHdanpersen teradsorpsi

Gambar 3. menunjukan bahwa persen teradsorpsi serapan ion logam $\mathrm{Cr}$ (total) pada $\mathrm{pH} 3$ dan 5 lebih kecil dibandingkan dengan persen teradsorpsi pada $\mathrm{pH} 7 \mathrm{dan} \mathrm{pH}$ 9. Hal ini terjadi karena permukaan adsorben cenderung terprotonasi atau lebih positif sehingga penolakan adsorben terhadap ion logam $\mathrm{Cr}$ (total) terjadi lebih cepat. Meningkatnya $\mathrm{pH}$ larutan maka ion $\mathrm{Cr}$ (total) yang terserap pada adsorben juga semakin bertambah hingga $\mathrm{pH}$ mencapai penyerapan optimum yaitu pada $\mathrm{pH}$ 7. Ion logam $\mathrm{Cr}$ (total) yang terserap mulai berkurang pada $\mathrm{pH}$ 9. Hal ini disebabkan karena peningkatan $\mathrm{pH}$ akan menyebabkan terlepasnya ion-ion ( karbonat ) ke dalam larutan, sehingga adsorpsi semakin berkurang

\section{Pengaruh Konsentrasi terhadap Adsorpsi Ion Logam Cr (Total)}

Optimasi konsentrasi larutan $\mathrm{Cr}$ (total) bertujuan untuk mengetahui kemampuan optimal adsorben pasir laut dalam menyerap ion logam $\mathrm{Cr}$ (total). Konsentrasi larutan $\mathrm{Cr}$ (total) yang digunakan yaitu 100, 150, 200, dan 250 ppm pada $\mathrm{pH}$ optimum. Data penentuan konsentrasi optimum larutan logam $\mathrm{Cr}$ (Total) dapat dilihat pada Gambar 4. 




Gambar 4. Hubungan antara konsentrasi dan persen teradsorpsi

Berdasarkan gambar 4. maka dapat diketahui kapasitas adsorpsi yang paling optimum adalah pasir hitam teraktivasi asam sulfat dengan konsentrasi $250 \mathrm{ppm}$. Dengan kapasitas adsorpsi 77,72 mg/l dengan prosentase sebesar 68,9\%. Pada pasir hitam teraktivasi asam sulfat dengan konsentrasi 100 ppm mendapat kapasitas adsorpsi 45,6 $\mathrm{mg} / \mathrm{l}$ dengan prosentase sebesar 54,4\%. tetapi setelah itu mengalami penurunan seiring bertambahnya konsentrasi, pasir hitam teraktivasi asam sulfat dengan konsentrasi 150 ppm mengalami penurunan drastis dengan kapasitas adsorpsi 130,88 $\mathrm{mg} / \mathrm{l}$ dan prosentase sebesar $12,7 \%$. Hal ini menunjukkan bahwa pasir laut yang diaktivasi dengan asam sulfat efektif untuk digunakan sebagai adsorben. Hal tersebut sesuai dengan teori bahwa aktivasi bertujuan untuk memperbesar pori sehingga pasir laut mengalami perubahan sifat, baik kimia maupun fisika dan berpengarus terhadap daya adsorpsi.

\section{Pengaruh Waktu Kontak terhadap Adsorpsi Ion Logam Cr (Total)}

Optimasi waktu kontak bertujuan untuk mengetahui kemampuan optimal adsorben pasir laut dalam menyerap ion logam Cr (total). Variasi waktu yang digunakan yaitu 30, 60, 90, dan 120 menit pada $\mathrm{pH}$ dan konsentrasi optimum. Data penentuan waktu optimum larutan logam $\mathrm{Cr}$ (Total) dapat dilihat pada Gambar 5. 


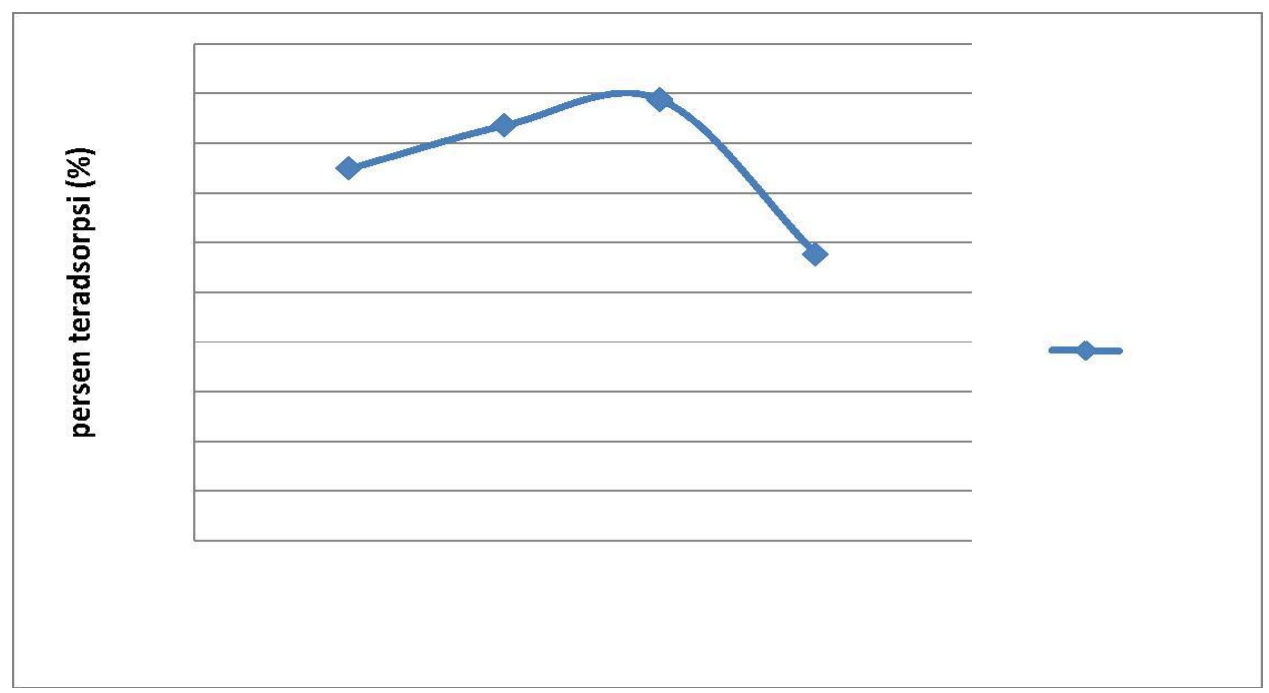

Gambar 5. Hubungan antara waktu kontak dengan persen teradsorpsi

Berdasarkan Gambar 5. maka dapat diketahui kapasitas adsorpsi yang paling optimum dari empat sampel di atas. Pada sampel yang menggunakan adsorben pasir hitam teraktivasi asam sulfat $250 \mathrm{ppm}$ kapasitas adsorpsi yang paling optimum adalah pada variasi waktu 90 menit dengan kapasitas adsorpsi 27,91 $\mathrm{mg} / \mathrm{l}$ dengan persentase sebesar $88,8 \%$.

Berdasarkan waktu kontaknya, kapasitas adsorpsi paling baik berada pada variasi waktu kontak 30 menit, 60 menit, dan 90 menit. Sedangkan pada variasi waktu 120 menit mulai terjadi penurunan kapasitas adsorpsi. Menurunnya penyerapan ini dikarenakan permukaan adsorben sudah terlalu jenuh dan ada kemungkinan terjadi desorpsi. Semakin lama waktu kontak antara ion logam $\mathrm{Cr}$ (total) dan pasir laut memungkinkan terjadinya peningkatan penyerapan ion logam. Interaksi yang terlalu lama dapat menurunkan tingkat penyerapan. Hal ini disebabkan semakin lama waktu kontak dapat mengakibatkan desorpsi, yaitu lepasnya ion logam Cr (total) yang sudah terikat pada gugus aktif adsorben.

\section{Aplikasi Pasir Laut Teraktivasi Asam Sulfat terhadap limbah pabrik kulit}

Pasir laut yang telah diaktivasi dan telah diketahui kondisi optimumnya akan digunakan untuk menurunkan kadar ion logam kromium dalam limbah industri pabrik kulit. Sampel limbah kromium ini 
didapatkan di industri pabrik kulit di Balai besar kulit daerah Yogyakarta.

Sebelum dilakukan adsorpsi terlebih dahulu mengukur konsentrasi awal limbah. Sampel digunakan pada adsorben pasir hitam. Data konsentrasi awal limbah pabrik kulit diperoleh dengan jalan pengukuran menggunakan SSA. Dan konsentrasi yang diperoleh adalah 1,86

Tabel 1. Data penyerapan ion logam $\mathrm{Cr}$ (total) menggunakan pasir laut terhadap limbah pabrik kulit

\begin{tabular}{|c|c|c|c|c|c|}
\hline Adsorben & $\begin{array}{c}\text { Massa } \\
\text { adsorben (g) }\end{array}$ & $\mathrm{pH}$ & $\begin{array}{c}\text { Waktu } \\
\text { (menit) }\end{array}$ & $\begin{array}{c}\text { Konsentrasi } \\
(\mathrm{mg} / \mathrm{L})\end{array}$ & $\begin{array}{c}\% \\
\text { Teradsorpsi }\end{array}$ \\
\hline Pasir Hitam & 6,5 & 7 & 90 & 0,33 & $82,2 \%$ \\
\hline
\end{tabular}

Massa yang digunakan pada adsorpsi di atas disesuaikan dengan konsentrasi awal limbah elektroplating. Setelah dilakukan analisis diperoleh kapasitas adsorpsi yang cukup besar dengan persen teradsorpsi 82,2 \%. Jenis pasir laut tersebut efektif digunakan sebagai adsorben apabila dimodifikasi dengan cara diaktivasi dengan asam sulfat 2M. Hal tersebut dikarenakan pasir laut hitam teraktivasi asam sulfat $2 \mathrm{M}$ dapat menurunkan kadar Cr(total) dalam limbah pabrik kulit hingga dibawah baku mutu yang telah ditetapkan.
mg/L. Pada penyerapan sampel limbah ini digunakan massa adsorben optimum untuk mengadsorpsi logam tembaga yang ada dalam sampel. Sampel kemudian menggunakan orbital shaker selama waktu optimum. Setelah diaduk sampel disaring dan filtratnya dianalisis dengan SSA. Hasil adsorpsi Kromium dalam sampel limbah oleh pasir laut dapat dilihat pada Tabel 1 . 
terlalu rendah konsentrasi kromium yang terserap semakin berkurang. Konsentrasi larutan $\mathrm{Cr}$ (total) yang berlebih menyebabkan jumlah kromium yang terserap cenderung stabil karena adsorben sudah jenuh. Semakin lama waktu kontak memungkinkan terjadinya peningkatan penyerapan. Namun jika terlalu lama dapat mengakibatkan desorpsi.

\section{DAFTAR PUSTAKA}

Atkins, .. (1999). Kimia fisik. jakarta: Erlangga.

Bradey., J. (1999). kimia untuk universitas. jakarta: Erlangga.

Chaudhuri and K, S. (1997). Treatment of Cadmium-Plating and Cromium-Plating wastes by iron oxide-coated sand.

DS Pambudi, A. P. (2014, april). Adsorpsiion $\mathrm{Cu}(\mathrm{II})$ menggunakan pasir laut teraktivasi $\mathrm{H} 2 \mathrm{SO} 4$ dan Tersalut $\mathrm{Fe} 2 \mathrm{O} 3$. Jurnal MIPA , 53-61.

dwimas, p. s. (2013). Adsorpsiion $\mathrm{Cu}$ (II) menggunakan pasir laut teraktivasi H2SO4Pemanfaatan pasir laut teraktivasi H2SO4 dan Tersalut Fe2O3 sebagai adsorben ion logam $\mathrm{Cu}(\mathrm{II})$ dalam larutan.
Giyatmi, Z. K. (2008, agustus). Penurunan kadar $\mathrm{Cu}, \mathrm{Cr}$ dan $\mathrm{Ag}$ dalam limbah cair industri perak.

Handayana, S. (1994). Kimia analitik instrumen. semarang: IKIP press Semarang.

Haryani, K. (2007). Pembuatan khitosan dari kulit udang untuk mengadsorpsi logam krom (Cr6+) dan tembaga $(\mathrm{Cu}) .86-90$.

K. Haryani, H. d. (2007). Pembuatan khitosan dari kulit udang untuk mengadsorbsi logam Krom (Cr6+) dan tembaga $(\mathrm{Cu}) .11,86-90$.

Kartohardjono, S. M. (2008). Penentuan kulit batang jambu biji (Psidium guajava) untuk adsorpsi Cr (VI) dari larutan.

menteri negara lingkungan hidup, $\mathrm{P}$. M. (2010). Baku mutu air limbah bagi kawasan

industri. jakarta: Ilyas Asaad.

Muhammad Said, A. W. (2008). Aktivasi zeolit alam sebagai adsorbent pada adsorpsi larutan iodium. jurnal teknik kimia , 15.

N. P. Elantiani Diantariani, I. W. (2008, januari). proses biosorpsi dan desrpsi ion $\mathrm{Cr}(\mathrm{VI})$ pada biosorben rumput laut eucheuma spinosum. 45-52. 
Ramadhan, S. (2005). kapasitas adsorpsi alga chlorella sp yang dimobilisasi silika gel terhadap ion logam Zn (II) dalam limbah industri pelapisan logam.

Slamet. (2005). Pengolahan limbah organik (fenol) dan logam berat (Cr6+ atau Pt4+) secra simultan dengan fotokatalis TiO2,ZZnO-TiO2, dan Cds-TiO2. 66-71.

Vogel. (1990). Buku teks analisis anorganik kualitatif makro dan semimikro (V ed.). jakarta: PT kalman media pustaka.

Widihati, I. A. (2008, januari). Adsorpsi anion $\mathrm{Cr}(\mathrm{VI})$ oleh batu pasir teraktivasi asam dan tersalut Fe2O3. 25-30. 